


\section{PUBLIC-PRIVATE PARTNERSHIPS}

GUIDANCE NOTE ON PROCUREMENT

JUNE 2018 


\section{(c) $(9)$ Creative Commons Attribution-NonCommercial-NoDerivs 3.0 BY NC ND IGO license (CC BY-NC-ND 3.0 IGO)}

(C) 2018 Asian Development Bank

6 ADB Avenue, Mandaluyong City, 1550 Metro Manila, Philippines

Tel +632632 4444; Fax +6326362444

www.adb.org

Some rights reserved. Published in 2018.

ISBN 978-92-9261-218-4 (print), 978-92-9261-219-1 (electronic)

Publication Stock No. TIM189410-2

DOI: http://dx.doi.org/10.22617/TIM189410-2

The views expressed in this publication are those of the authors and do not necessarily reflect the views and policies of the Asian Development Bank (ADB) or its Board of Governors or the governments they represent.

ADB does not guarantee the accuracy of the data included in this publication and accepts no responsibility for any consequence of their use. The mention of specific companies or products of manufacturers does not imply that they are endorsed or recommended by ADB in preference to others of a similar nature that are not mentioned.

By making any designation of or reference to a particular territory or geographic area, or by using the term "country" in this document, $\mathrm{ADB}$ does not intend to make any judgments as to the legal or other status of any territory or area.

This work is available under the Creative Commons Attribution-NonCommercial-NoDerivs 3.0 IGO license (CC BY-NC-ND 3.0 IGO) http://creativecommons.org/licenses/by-nc-nd/3.o/igo/. By using the content of this publication, you agree to be bound by the terms of this license. For attribution and permissions, please read the provisions and terms of use at https://www.adb.org/terms-use\#openaccess.

This CC license does not apply to non-ADB copyright materials in this publication. If the material is attributed to another source, please contact the copyright owner or publisher of that source for permission to reproduce it. ADB cannot be held liable for any claims that arise as a result of your use of the material.

Please contact pubsmarketing@adb.org if you have questions or comments with respect to content, or if you wish to obtain copyright permission for your intended use that does not fall within these terms, or for permission to use the ADB logo.

Notes:

In this publication, “\$” refers to United States dollars.

Corrigenda to ADB publications may be found at http://www.adb.org/publications/corrigenda. 


\section{CONTENTS}

Figure $\quad$ iv

About This Publication $\quad$ v

Abbreviations viii

Executive Summary $\quad$ ix

$\begin{array}{ll}\text { I. Introduction } & 1\end{array}$

II. Procurement Principles 3

III. Key Considerations in Public-Private Partnership Procurement 5

IV. Resources for Further Review 8 


\section{ABOUT THIS PUBLICATION}

In April 2017, the Asian Development Bank (ADB) approved its new procurement framework, the ADB Procurement Policy: Goods, Works, Nonconsulting and Consulting Services (2017, as amended from time to time); and the Procurement Regulations for ADB Borrowers: Goods, Works, Nonconsulting and Consulting Services (2017, as amended from time to time). These replace the former Guidelines on the Use of Consultants (2013, as amended from time to time) and Procurement Guidelines (2015, as amended from time to time). The procurement policy and the procurement regulations address the procurement activities of project executing agencies and implementing agencies on projects financed in whole or in part by a loan or grant from ADB, or by ADB-administered funds. ADB designed the 2017 procurement policy to deliver significant benefits and flexibility throughout the project procurement cycle, as well as to improve project delivery through a renewed focus on the concepts of quality, value for money (VFM), and fitness for purpose.

This note is part of a series of guidance notes published by ADB in 2018 to accompany the 2017 procurement policy and the procurement regulations. Each note discusses a topical issue for borrowers (including grant recipients), bidders, and civil society under the new framework (see list below). The guidance notes cross-reference each other frequently and should be read in conjunction. All references to "guidance notes" pertain to these notes. The notes may be updated, replaced, or withdrawn from time to time.

\section{List of Guidance Notes for the 2017 ADB Procurement} Policy and the Procurement Regulations

1. Value for Money

2. Procurement Risk Framework

3. Strategic Procurement Planning

4. Procurement Review

5. Alternative Procurement Arrangements

6. Open Competitive Bidding

7. Price Adjustment

8. Abnormally Low Bids

9. Domestic Preference

10. Prequalification

11. Subcontracting

12. Consulting Services Administered by ADB Borrowers

13. Nonconsulting Services Administered by ADB Borrowers
14. High-Level Technology

15. Quality

16. Bidding-Related Complaints

17. Noncompliance in Procurement

18. Standstill Period

19. State-Owned Enterprises

20. E-Procurement

21. Framework Agreements for Consulting Services

22. Public-Private Partnerships

23. Contract Management

24. Fragile, Conflict-Affected, and Emergency Situations 
ADB procurement reforms intend to ensure VFM by improving flexibility, quality, and efficiency throughout the procurement cycle (see illustration below and the Guidance Note on Value for Money). VFM is part of a holistic procurement structure with three support pillars: efficiency, quality, and flexibility. The two key principles of transparency and fairness weave across all elements of the structure.

\section{Transparency}

\section{Value for Money}

The effective, efficient, and economic use of resources, which requires an evaluation of relevant costs and benefits along with an assessment of risks, nonprice attributes, and/or total cost of ownership as appropriate

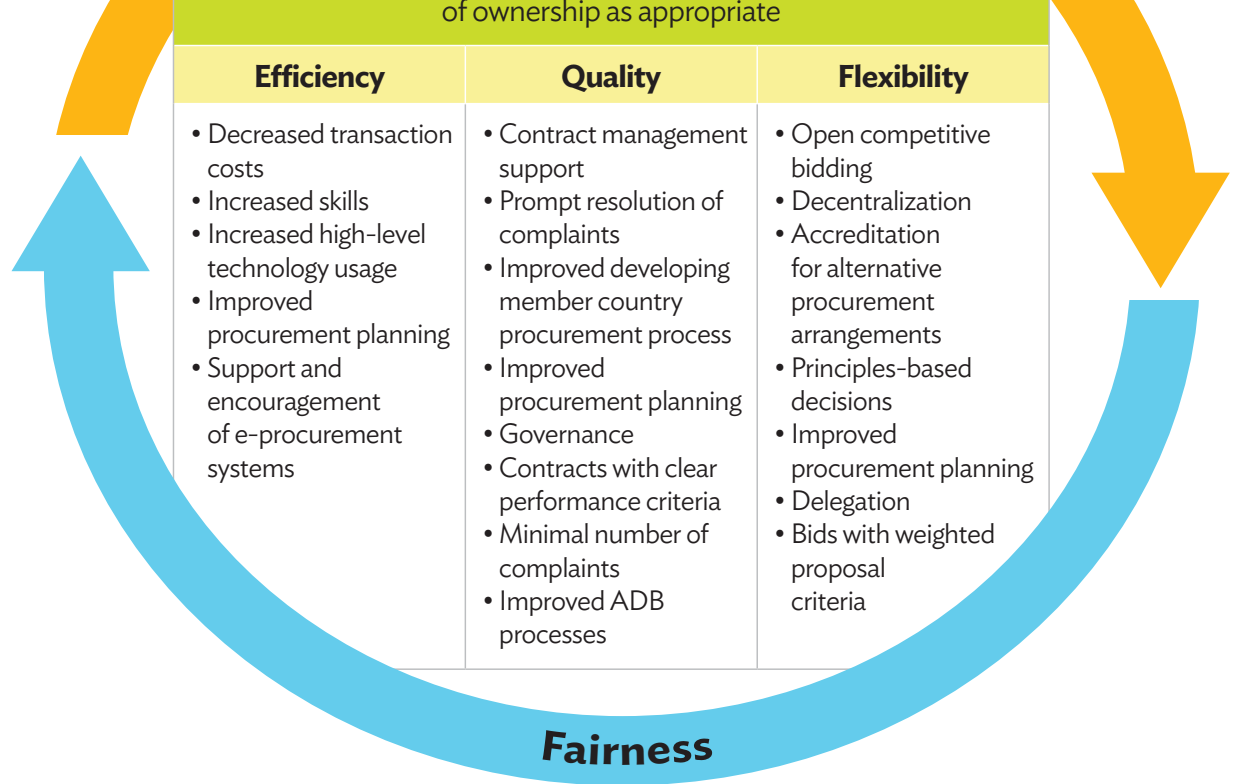

\section{(1) Time}

Time is an important element of VFM. When a project is delivered promptly or when a process is completed rapidly, greater value is created for all stakeholders. For example, a road project completed early provides economic benefit, security, or other value to the community it serves. It increases the return on investment to the executing agency and accelerates the project and payment cycle to the successful bidder. Likewise, a project delivered late loses significant value.

When considering VFM in the context of procurement, pay attention to anything that (i) shortens the procurement cycle time frame or (ii) accelerates delivery of the development project. 


\section{$\Omega$ Objective}

This guidance note is intended to assist readers by elaborating on and explaining ADB's 2017 procurement policy and procurement regulations for borrowers (including grant recipients).

This note identifies additional information for the reader to consider when applying ADB's procurement policy and procurement regulations to their circumstances.

\section{F Living Document}

This guidance note is intended to be a living document and will be revised as required.

Be sure to check the ADB Business Center website for the latest version and updates, https://www.adb.org/business/main.

\section{? The Reader}

In many circumstances, readers are expected to use this guidance note in a manner unique to their needs. For consistency throughout the suite of guidance notes, the following assumption is made about the reader:

The reader is a professional involved in activities financed in whole or in part by an ADB loan or grant, or by ADB-administered funds.

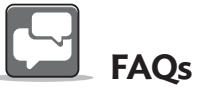

Frequently asked questions, clarifications, examples, additional information, links to training, and other useful resources will be made available on the ADB website.

Be sure to check the ADB Business Center website for more information, https://www.adb.org/business/main.

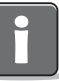

\section{Legal and Order of Priority}

This guidance note explains and elaborates on the provisions of the Procurement Regulations for ADB Borrowers: Goods, Works, Nonconsulting and Consulting Services (2017, as amended from time to time) applicable to executing (and implementing) agencies under sovereign (including subsovereign) projects financed in whole or in part by an investment loan from ADB (i.e., excluding ADB results- or policy-based loans), ADB-financed grant (excluding ADB-administered technical assistance and staff consultancies), or by ADB-administered funds.

In the event of any discrepancy between this guidance note and the procurement regulations, the latter will prevail. The financing agreement governs the legal relationships between the borrower and ADB. The rights and obligations between the borrower and the provider of goods, works, or services are governed by the specific procurement document issued by the borrower and by the contract signed between the borrower and the provider, and not by this guidance note. 


\section{ABBREVIATIONS}

$\begin{array}{lll}\text { ADB } & - & \text { Asian Development Bank } \\ \text { PPP } & - & \text { public-private partnership } \\ \text { VFM } & - & \text { value for money }\end{array}$


This guidance note applies to the selection of public-private partnership (PPP) operators for sovereign lending operations only. It does not apply to nonsovereign operations; downstream procurement of goods, works, and services by the private operator; transaction advisory services provided by ADB; or regional project preparation facilities, country-specific project development facilities, and project preparation facilities resulting from ADB technical assistance and sovereign lending.

The six core procurement principles stated in the ADB procurement policyeconomy, efficiency, fairness, transparency, quality, and value for money (VFM) all apply to PPP procurement. Although the nature of PPP procurement is different from the conventional procurement of goods, works, and services, the process for procuring PPPs should be designed and implemented to comply with these principles.

A PPP refers to a long-term contractual arrangement between public (national, state, provincial, or local) and private entities through which skills, assets, and/or financial resources of each of the public and private sectors are allocated in a complementary manner - thereby sharing the risks and rewards, to seek to provide optimal service delivery, and good value to citizens.

PPPs may be characterized as follows:

- long duration,

- complex financing,

- life cycle responsibilities managed by the private sector partner,

- $\quad$ performance-based returns, and

- output-specified.

VFM in PPP projects is achieved through the leveraging of private sector efficiency, effectiveness, and economy, and through the appropriate allocation of risks.

Despite PPP projects being different in nature from conventional projects, the procurement process is similar, comprising planning, bidding, bid evaluation, contract award, and implementation. The methods used in each of these steps vary from conventional procurement because of the nature of PPP projects, being long-term and output-focused.

Extensive literature on PPP procurement is publicly available from ADB, the World Bank, other multilateral development banks, APM Group International, and others. 



\section{Introduction}

\section{A. Purpose}

1.1 The purpose of this guidance note is to describe the procurement principles applying to public-private partnerships (PPP), to highlight particular considerations in PPP procurement, and to provide references to some of the extensive literature available on PPP establishment, procurement, and management.

\section{B. Scope}

1.2 The Asian Development Bank (ADB) supports PPP arrangements in several ways:

(i) technical assistance, aimed at enabling and preparing PPPs by fostering policy and regulatory reforms, capacity building, and project preparation studies;

(ii) transaction advisory services to (a) government entities engaged in the design, preparation, and procurement of PPPs; and (b) private sector operators;

(iii) sovereign lending operations to governments to finance their participation in PPPs;

(iv) nonsovereign lending operations directly to private sector operators or indirectly to financial intermediaries that will, in turn, finance private sector investors;

(v) equity investments to private sector operators, either as an investment in a company (or a holding company) that, in turn, takes an equity participation in a special purpose vehicle, or directly as an equity participation in a special purpose vehicle; and

(vi) guarantees to cover political risks or both political and credit risks.

1.3 This guidance note applies to the selection of a PPP operator, where the project is jointly cofinanced by ADB through its sovereign financing window only. 
1.4 This guidance note does not apply to

(i) nonsovereign operations;

(ii) procurement of goods, works, and services by the private operator selected to implement the PPP contract (sometimes known as "downstream" procurement);

(iii) transaction advisory services provided by ADB to borrowers, public sector entities, and private sector operators; and

(iv) regional project preparation facilities, country-specific project development facilities, and project preparation facilities resulting from ADB technical assistance and sovereign lending. 


\section{Procurement Principles}

\section{A. Definition of Public-Private Partnerships}

2.1 A PPP refers to a long-term contractual arrangement between public (national, state, provincial, or local) and private entities through which the skills, assets, and/or financial resources of each of the public and private sectors are allocated in a complementary manner-thereby sharing the risks and rewards, to seek to provide optimal service delivery and good value to citizens.

2.2 PPPs may be characterized by the following four elements:

(i) Duration. Contracts between public and private sector partners are usually medium- to long-term, often covering the lifetime of the asset being produced under the PPP contract.

(ii) Financing, responsibilities, and ownership. Asset financing by the public and/or private sector is often complex and can involve revenues obtained from the operation of the asset over a designated period. Responsibility for constructing, operating, and maintaining the asset can often be included in the responsibilities of the private partner. Ownership of the asset varies by PPP arrangement. In some cases, the private sector operator owns the asset and transfers ownership to the public sector partner after a designated period. In other cases, ownership is shared or may be retained by the public sector partner over the life of the asset.

(iii) Performance-based returns. PPPs develop assets or projects for the purpose of delivering ongoing services to the public, rather than the asset being the deliverable of the contract, with payment being contingent on the operator of the asset meeting performance standards. The public sector partner is usually responsible for monitoring performance over the life of the contract.

(iv) Output and quality specification. The private sector partner participates in stages of the project defined by the public sector partner (e.g., design, construction, operation, maintenance, and financing). The public sector partner defines the outcomes to be achieved in terms of public interest, quality of services provided, and pricing policy. 


\section{B. Applicability of Core Procurement Principles}

2.3 The six core procurement principles stated in the ADB Procurement Policy: Goods, Works, Nonconsulting, and Consulting Services (2017, as amended from time to time) - economy, efficiency, fairness, transparency, quality, and value for money (VFM) - all apply to PPP procurement. Although the nature of PPP procurement is different from conventional procurement of goods, works, and services, the process for procuring PPPs should be designed and implemented to comply with these principles.

2.4 VFM in PPP projects is achieved through the leveraging of private sector efficiency, effectiveness, and economy, and through the appropriate allocation of risks.

2.5 The factors that determine whether a project delivers VFM will vary by type of project, sector, and country. In general, PPPs can generate improved VFM for the procuring authority in several ways, including

(i) reduced total cost of ownership (whole life cycle costs),

(ii) better allocation of risks,

(iii) streamlined and efficient project implementation,

(iv) improved quality of service, and

(v) potential to unlock additional revenue streams.

2.6 More information on VFM in PPP projects can be found in the ADB Public-Private Partnership Operational Plan, 2012-2020.'

ADB. 2012. Public-Private Partnership Operational Plan 2012-2020. Manila. https://www.adb.org/ documents/public-private-partnership-operational-plan-2012-2020. 


\section{Key Considerations in Public-Private Partnership Procurement}

3.1 PPP projects vary from traditional projects in several important ways, which affect the procurement approach and procurement methods. These include the following:

(i) PPP contracts are usually long-term and the environment in which the PPP operates over the life of the partnership can change in unforeseen ways. This may require the selection of criteria used to evaluate proposals that are different from those used in conventional procurement, in which requirements over the life of the contract are more clearly known.

(ii) PPP contracts generally involve the private sector partner constructing the asset and then operating and maintaining it. The public sector partner usually specifies requirements in terms of outputs, e.g., megawatts of power output of a power plant, rather than the conventional procurement approach of specifying inputs, such as the specifications of the type and size of plant.

(iii) The private sector operator will generally have an equity stake in the entity (special purpose vehicle or project company) that will procure the asset, and will receive or share revenue generated by the asset, rather than the conventional procurement approach of being paid for provision of goods or services or for the construction of an asset. This changes the balance of risk in the relationship and the nature of the contract management task over the course of the contract.

3.2 Despite these significant differences, the process used to procure a PPP arrangement has similar steps with conventional procurement. The steps in PPP procurement include those described in the ADB procurement cycle (see Figure), including procurement planning, bidding, bid evaluation, contract award, and contract implementation and management.

\section{A. Procurement Planning}

3.3 Section 7 of the ADB Public-Private Partnership Handbook notes that the procurement method will depend on the government's budget, capacity, desire to encourage innovation, need for high-level inputs, vulnerability to corruption, and 
Figure: The ADB Procurement Cycle

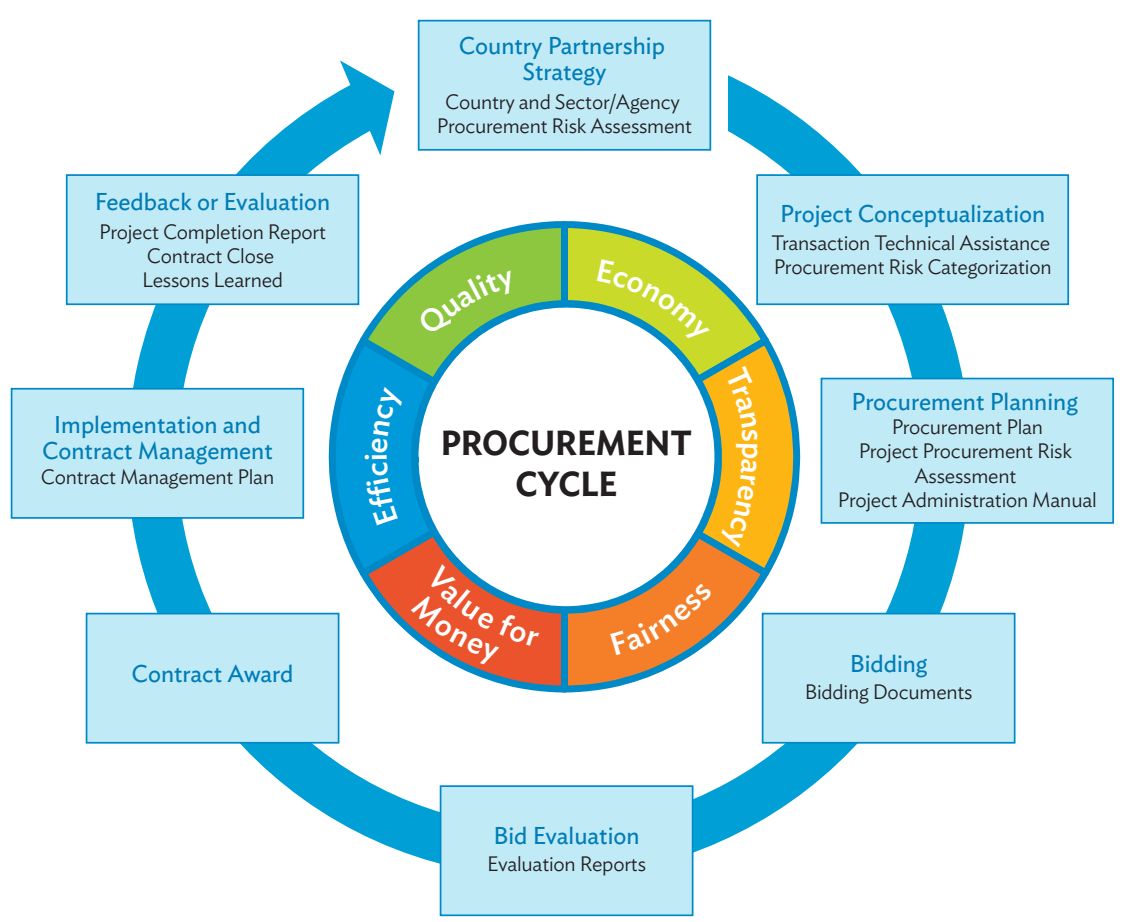

Source: Asian Development Bank.

objectives of the PPP project. ${ }^{2}$ It notes the three main options of (i) unsolicited proposals or direct negotiations ("sole sourcing"), (ii) competitive negotiations, and (iii) competitive bidding.

3.4 In the case of unsolicited proposals, decisions may need to be made about the procurement approach in place of (or as part of) the procurement planning stage of the ADB procurement cycle.

3.5 The Public-Private Partnerships Reference Guide, developed by a collaboration of multilateral development banks, also provides information on considerations when deciding the procurement strategy, including (i) whether to use prequalification; (ii) whether to use a single-stage or multistage bid process;

2 ADB. 2008. Public-Private Partnership Handbook. Section 7: Implementing PPPs, Subsection 7.3: Defining the Procurement Process. Manila. https://www.adb.org/documents/public-privatepartnership-ppp-handbook. 
(iii) to what extent negotiations and discussions will take place with one or more bidders; and (iv) whether proposals will be evaluated on the basis of financial or value-related criteria, or a combination of both. ${ }^{3}$

3.6 The PPP reference guide (in Table 3.3) also notes the importance of considering the requirements and limitations of country PPP and procurement law on the procurement strategy options and procurement procedures available to public sector partners conducting PPP procurement (footnote 3 ).

\section{B. Procurement Process and Contract Management}

3.7 The ADB PPP handbook provides guidance on the procurement process applied to PPP procurement (footnote 2), including

(i) typical competitive bidding process;

(ii) bid evaluation process (including weighted technical and financial criteria, pass/fail technical criteria, and weighting of criteria);

(iii) contents of a bid package;

(iv) contents of a PPP contract;

(v) contract negotiations; and

(vi) contract implementation and management.

3.8 The PPP reference guide also provides information on the PPP procurement process, including drafting the PPP contract, managing the PPP transaction (the bidding process), and managing the PPP contract (footnote 3 ).

3.9 In addition, the Public-Private Partnership Certification Guide from APM Group International provides extensive information and guidance on considerations in the PPP procurement process, including "Chapter 5, Structuring and Drafting the Tender and Contract"; "Chapter 6, Tendering and Awarding the Contract"; and "Chapter 7, Managing the Contract."

3.10 The APM Group International's PPP Certification Guide notes the importance of contract management (comprising governance, contract administration, relationship management, and performance management), noting that, while the private partner has the responsibility of implementing the contract, it is essential that the public sector partner puts in place a management process to ensure timely completion and satisfactory operation. ${ }^{4}$ Just as in conventional procurement, significant value can be lost through poor contract management.

3 World Bank, et al. 2017. Public-Private Partnerships Reference Guide, Version 3. Washington, DC. https://pppknowledgelab.org/guide/sections/83-what-is-the-ppp-reference-guide.

4 ADB, et al. 2016. Public-Private Partnership Certification Guide. Chapter 7: Strategy, Delivery and Commissioning, Sections 3 and 4. Buckinghamshire: APM Group International. https://pppcertification.com/pppguide/download. 


\section{Resources for Further Review}

4.1 For more advice and guidance on PPPs, among other sources, refer to

(i) ADB. 2017. Public-Private Partnership Monitor. Manila.

https://www.adb.org/publications/public-private-partnership-monitor.

(ii) ADB, et al. 2016. Public-Private Partnership Certification Guide.

Buckinghamshire: APM Group International.

https://ppp-certification.com/pppguide/download.

(iii) ADB. 2012. Public-Private Partnership Operational Plan 2012-2020.

Manila.

https://www.adb.org/documents/public-private-partnershipoperational-plan-2012-2020.

(iv) ADB. 2008. Public-Private Partnership Handbook. Manila.

https://www.adb.org/documents/public-private-partnership-ppphandbook.

(v) Independent Evaluation Group. 2015. World Bank Group Support to Public-Private Partnerships: Lessons from Experience in Client Countries, FY02-12. Washington, DC: World Bank Group.

https://openknowledge.worldbank.org/handle/10986/21309.

(vi) Office of Evaluation and Oversight. 2017. Evaluation of Public-Private

Partnerships in Infrastructure. Washington, DC: Inter-American

Development Bank.

https://publications.iadb.org/bitstream/handle/11319/8200/

Evaluation-of-Public-Private-Partnerships-in-Infrastructure. pdf? sequence $=9$.

(vii) PPP in Infrastructure Resource Center. 2017. Benchmarking PPP Procurement 2017. Washington, DC: World Bank Group.

https://ppp.worldbank.org/public-private-partnership/library/ benchmarking-ppp-procurement-2017.

(viii)PPP in Infrastructure Resource Center. 2017. Toolkits for Public-Private Partnerships. Washington, DC: World Bank Group.

https://ppp.worldbank.org/public-private-partnership/overview/ practical-tools/toolkits.

(ix) World Bank Group, et al. 2017. Public-Private Partnerships Reference Guide, Version 3. Washington, DC.

https://pppknowledgelab.org/guide/sections/83-what-is-the-pppreference-guide.

4.2 In addition, the ADB PPP handbook lists extensive reference resources in section 10, Resources and Tools, including websites and literature. 


\section{Public-Private Partnerships}

\section{Guidance Note on Procurement}

This guidance note discusses the selection of public-private partnership (PPP) operators for ADB's sovereign lending operations. It describes the procurement principles applying to these PPPs; highlights particular considerations in PPP procurement; and provides references to some of the extensive literature available on PPP establishment, procurement, and management.

\section{About the Asian Development Bank}

ADB's vision is an Asia and Pacific region free of poverty. Its mission is to help its developing member countries reduce poverty and improve the quality of life of their people. Despite the region's many successes, it remains home to a large share of the world's poor. ADB is committed to reducing poverty through inclusive economic growth, environmentally sustainable growth, and regional integration.

Based in Manila, ADB is owned by 67 members, including 48 from the region. Its main instruments for helping its developing member countries are policy dialogue, loans, equity investments, guarantees, grants, and technical assistance.

\section{$\mathrm{ADB}$}

